\title{
Diallel Analysis for Lycopene Content in the Hybrids Derived from Different Colored Parents in Tomato
}

\author{
Dilip R. Panthee1 ${ }^{*}$, Penelope Perkins-Veazie ${ }^{2}$, Candice Anderson ${ }^{1}$, Ragy Ibrahem ${ }^{1}$ \\ ${ }^{1}$ Department of Horticultural Science, North Carolina State University, Mountain Horticultural Crops Research \\ and Extension Center, Mills River, NC, USA \\ ${ }^{2}$ Department of Horticultural Science, North Carolina State University, Plants for Human Health Institute, \\ Kannapolis, NC, USA \\ Email: "dilip panthee@ncsu.edu
}

Received 26 May 2015; accepted 6 June 2015; published 23 June 2015

Copyright (C 2015 by authors and Scientific Research Publishing Inc.

This work is licensed under the Creative Commons Attribution International License (CC BY).

http://creativecommons.org/licenses/by/4.0/

(c) (i)

\section{Abstract}

Lycopene is a red pigment in tomato with purported antioxidant properties. As the amount of lycopene has been reported to differ in different colored tomatoes or even absent in non-red tomatoes, the objective of this study was to investigate the inheritance of lycopene content and the color parameters of hybrids using a 10 parent diallel excluding reciprocals. Parents differed in general combining ability (GCA) for lycopene and color parameters. "Chocolate Stripe" (purple and brown striped) had the highest lycopene content followed by NC 1CS (red colored with the crimson gene) with the best general combining ability among parental lines. Hybrids differed in lycopene content and color parameters across two summer and greenhouse experiments, with no interaction between experiments indicating that the lycopene content was consistent. Narrow-sense heritability for lycopene was only $9 \%$ whereas broad-sense heritability was estimated to be $25 \%$. The order of dominance for lycopene content was found as purple-brown $>$ red $>$ blue $>$ yellow $>$ green. Heritability estimates for color parameters were close to those for lycopene. This information may be useful in developing specialty type tomatoes or increasing lycopene content in tomatoes.

\section{Keywords}

Diallel, General Combining Ability (GCA), Heritability, Lycopene, Tomato, Specific Combining Ability (SCA)

\footnotetext{
${ }^{*}$ Corresponding author.
}

How to cite this paper: Panthee, D.R., Perkins-Veazie, P., Anderson, C. and Ibrahem, R. (2015) Diallel Analysis for Lycopene Content in the Hybrids Derived from Different Colored Parents in Tomato. American Journal of Plant Sciences, 6, $1483-1492$. http://dx.doi.org/10.4236/ajps.2015.69147 


\section{Introduction}

Consumers tend to make initial purchases of tomatoes based on external features such as color and appearance, making tomato fruit color an important trait. While red fruit color is dominant in most of the cases, there is a special demand for different colored tomatoes, especially: pink, bicolor (combination of two colors), yellow, orange, green and blue [1]. Tomato fruit color can largely be explained by mutations in the carotenoid pathway. A brief overview of the pathway follows (for a more complete review see Lu and Li [2]): yellow flesh ( $r$-mutants) caused by a mutation in phytoene synthase (PSY) [3] [4], tangerine flesh color ( $t$-mutants) caused by mutations in prolycopene isomerase (CrtISO), accumulation of lycopene resulting in deep red fruit $\left(\mathrm{og} / \mathrm{og}^{c}\right)$ caused by mutations in $\beta$-cyclase [5] [6] and pink tomatoes caused by the $y$ mutation which makes the fruit epidermis clear instead of yellow [7]. Lycopene is an important color pigment since the amount of lycopene is determined based on color intensity, particularly red component of the tomato. Lycopene has been shown to have: anti-cancer and anti-oxidant properties [8]-[10], and prevent cardio-vascular diseases [11] and diabetes [12]. The increased consumer awareness and the demand for food containing bioactive compounds, make lycopene a key trait for tomato breeders to select for [13]. As the importance of the interrelated traits of color and bioactive compounds increase for consumers, the genetics of fruit color becomes increasingly important for tomato breeders-a subject that has not been thoroughly investigated outside of the laboratory.

While tomato is rich in lycopene, isomer type and availability upon consumption of fresh fruit are under discussion. It has been reported that the cis-isomer of lycopene is more readily absorbed than the trans-isomers, the major form in raw tomato [14] [15]. Tomato breeding challenges include increasing lycopene content and cislycopene isomers.

It has been realized by consumers as well as researchers for a long time that fruit quality including lycopene is the important trait to improve [16]. Realizing this fact, some efforts have been made in the past at NC State University, which resulted in some improved varieties released with improved fruit color [17] [18]. It has been reported that there is a positive correlation between fruit color and lycopene concentration [19]. Vogel et al. [20] used tomato genotypes with tangerine ( $t$-mutant: LA3183), old gold (og-mutant: LA3179), yellow flesh ( $r$-mutant: LA3691) and a control genotype (Alisa Craig) with red fruit. Carotenoid profiles and amounts differed among mutants. The $r$-mutant did not have any carotenoids whereas the $t$-mutant and og-mutant had a reduced level of $\beta$-carotene but an increased level of trans-lycopene, respectively.

The objective of this study was to investigate the inheritance of lycopene content and the color parameters of hybrids derived from tomato genotypes from diallel cross combinations excluding reciprocals. In this paper, we report the findings of experiments involving diallel crosses derived from 10 parents of different colors. Inheritance of fruit colorin tomato has not been reported, which may be interesting for tomato breeders aiming to improve specialty types of tomatoes.

\section{Materials and Methods}

\subsection{Plant Materials}

Ten tomato genotypes with different fruit color were selected as parents. Genotypes used in the crosses are described below:

1. "NC1CS" is a large-fruited fresh-market tomato breeding line with the "crimson" $\left(\operatorname{og}^{c}\right)$ gene. It has large, smooth fruits and flesh is dark red in ripe fruits [21].

2. "NC74CAP (2009)-Bk" has blue skin color, and small round fruited. Plant has determinate growth habit.

3. "NC72LYC (2009)-Bk" has yellow color with the $\beta$-gene.

4. "NC08133-1(x)-7W" has yellow and red stripes on the skin.

5. "NC28L-1(2008)" has large fruits with red color.

6. "NC95LYC (2009)-Bk" has large fruits with ( $r$-mutant) yellow color.

7. "NC1Y" has yellow fruits with the "tangerine" $(t)$ gene.

8. "Chocolate Stripe" has jumbo fascinated fruits with brown-purple stripes. This is an heirloom variety with indeterminate growth habit.

9. "Malachite Box" also has jumbo fascinated fruits with green flesh color. It has indeterminate growth habit.

10. "NC161L" [22] has pink fruit color and determinate growth habit.

All parents were crossed in diallel combinations without reciprocals to produce $45 \mathrm{~F}_{1}$ hybrids in the fall season of 2009. Four experiments were conducted including $45 \mathrm{~F}_{1}$ hybrids and 10 parents in the field (summer of 
2010 and 2011) and in the greenhouse (2010 spring and 2011 fall) at the Mountain Horticultural Crops Research and Extension Center, Mills River, NC,

Seeds were planted in 72 cell flats $\left(56 \times 28 \mathrm{~cm}^{2}\right)$ in potting mix and transplants, at about 6 weeks from seed were planted by hand in the field for summer experiments, and in the plastic pot for greenhouse experiments. Plants of each genotype were planted with $45 \mathrm{~cm}$ of plant-to-plant, and $150 \mathrm{~cm}$ row-to-row spacing in the field for summer experiments. The soil was a clay-loam and the natural day light photoperiod was about 14/10 hr with $25^{\circ} \mathrm{C}-30^{\circ} \mathrm{C}$ high and $14^{\circ} \mathrm{C}-16^{\circ} \mathrm{C}$ low temperatures. Similar temperatures and photoperiods were maintained in the greenhouse.

An experimental unit consisted of four plants in the greenhouse experiments and six plants in the field experiments. They were arranged in a randomized complete block design (RCBD) with three replications in each experiment. Parents and their $\mathrm{F}_{1 \mathrm{~s}}$ were planted in a three gallon $\left(11356.24 \mathrm{~cm}^{3}\right)$ plastic pot using potting mix in the greenhouse. Fruits were harvested when they were ripe.

\subsection{Color Capturing and Image Analysis with the Tomato Analyzer (TA)}

Fully ripe fruit (USDA stage 6) were harvested from the middle four plants from each line. Fruit were taken to the horticulture laboratory immediately after harvest and rinsed with tap water to remove debris and then air dried. A minimum of six fruit per genotype, free of injury, were sliced in half longitudinally (from stem to blossom end) with a sharp knife.

Tomato Analyzer (TA) software [ver. 2.2 (http://www.oardc.ohio-state.edu/vanderknaap/tomato_analyzer.htm)] [23] was used to obtain color parameters CIE $\mathrm{L}^{*}, \mathrm{a}^{*}, \mathrm{~b}^{*}$, hue and chroma estimates. Images were taken from cut fruits using a flatbed scanner (Canon Image Scanner CanoScan 8800F Canon, Melville, NY). The scanner and fruit were covered with a cardboard box with a black background to avoid effects of ambient light. Detailed instruction on taking images of tomato fruits is described by Rodríguez, Moyseenko [24]. Images of at least six fruit per line were taken and saved as ".JPEG" file. The Tomato Analyzer was used to estimate the color parameters $\mathrm{L}^{*}, \mathrm{a}^{*}$ and $\mathrm{b}^{*}$ of the image. Average data of all fruit per scan was entered in an Excel file for further analysis.

\subsection{Lycopene Determination}

Following the above measurements, about 250 - $400 \mathrm{~g}$ of tomato (one-half slice per fruit) was placed in plastic zip lock bags and held at $-80^{\circ} \mathrm{C}$ until analyzed for lycopene. Tomato slices were thawed and pureed using a homogenizer (Polytron PT10-35-GT with 20 mm PTDA generator, Kinematica, Bohemia, NY). Diluted purees (1:4 w/w water) were mixed in $50 \mathrm{~mL}$ centrifuge tubes then $20 \mathrm{~mL}$ poured into a $10 \mathrm{~cm}$ cuvette. Absorbance at $350 \mathrm{~nm}$ to $760 \mathrm{~nm}$ was measured using a Hunter Lab Ultra Scan Pro equipped with diffuse/8 xenon illumination (Hunter Associates, Reston, VA). Lycopene was calculated by subtracting the peak area at $750 \mathrm{~nm}$ (background light scatter) from that at $560 \mathrm{~nm}$ (the peak absorbance wavelength for total lycopene). Total lycopene was calculated using the system of Davis et al. [25]. Lycopene values were verified using HPLC and spectrophotometer analyses according to Perkins-Veazie, Collins [26] (data not shown).

\subsection{Data Analysis}

Analysis of variance (ANOVA) of lycopene and color parameters (L, $\mathrm{a}^{*}, \mathrm{~b}^{*}$, hue and chroma) of $\mathrm{F}_{1}$ and parents for each experiment and over experiments were carried out separately using SAS software [27]. The ANOVA model over experiments assumed genotypes to be the fixed effect and experiments to be random. Genotypic differences among experiments were separated by least significant difference (LSD) at 5\% probability level. Combining ability analyses of $F_{1 s}$ were conducted separately according to Griffing [28] by using method 4 (partial diallel including parents) and model 1 (fixed effect) as described in Diallel-05 [29] to estimate the general (GCA) and specific combining ability (SCA) effects. Variance components were also estimated by the same models.

\section{Results}

\subsection{Parents and $\mathrm{F}_{1 \mathrm{~s}}$ Means}

Among the parents, Chocolate Stripe $(74.9 \mathrm{mg} / \mathrm{kg}$ ) was highest for lycopene content followed by NC 1CS (69.3 $\mathrm{mg} / \mathrm{kg}$ ) and NC161L (64.6 mg/kg). Level of lycopene in Chocolate Stripe was the same across the environments 
indicating that it was producing in the similar levels of lycopene in each experiment. NC1CS (dark red) and NC $161 \mathrm{~L}$ (pink) were also one of the top lycopene containing parent lines. Dark red color in NC 1CS is because of the crimson gene, which gives the gel an orange color. The pink color of NC161L is due to red flesh and a clear (transparent) skin. High lycopene content in the pink colored tomato indicated that probably the lycopene was being measured from flesh itself. Yellow color genotypes such as 08133-1(×)-7W and NC 1Y had much less lycopene as expected. Another yellow color genotype NC95LYC (2009) had no detectable lycopene. Levels of lycopene of different parents are given in Table 1.

\subsection{Crosses with Purple Brown Parent}

Chocolate Stripe was the parent with a purple brown stripe and a high lycopene content, Chocolate Stripe $\times$ NC $161 \mathrm{~L}$ produced better hybrids $(70.2 \mathrm{mg} / \mathrm{kg})$ than Chocolate Stripe $\times$ Malachite Box $(63.8 \mathrm{mg} / \mathrm{kg})$ since NC 161L was better than Malachite Box for lycopene. Similarly, NC 1CS $\times$ Chocolate Stripe hybrid was better (66.1 $\mathrm{mg} / \mathrm{kg}$ ) than 08133-1(×)-7Wx Chocolate Stripe $(60.3 \mathrm{mg} / \mathrm{kg}$ ) hybrid for lycopene level since the latter cross involved a yellow fruited parent (Table 1). All crosses with Chocolate Stripe had the best level of lycopene in every environment. This indicated that Chocolate Stripe was one of the parents with best GCA.

\subsection{Crosses with Red Fruited Parents}

Red fruited parents were NC 1CS and 28L-1 (2008). NC 1CS combined extremely well with all other parents including red, yellow, blue, pink, green and a mixture of purple and brown colored tomato lines for lycopene content as well as color parameters. Even with the yellow parents, lycopene was present when crossed with yellow and green parents (Table 1). Hybrids involving yellow parents including 95LYC (2009), 08133-1(×)-7W and NC 1Y produced reduced levels of lycopene. For example, NC 1CS $\times 08133-1(\times)-7 \mathrm{~W}$ hybrid had 61.4 $\mathrm{mg} / \mathrm{kg}$ whereas NC 1CS $\times$ NC 1Y had 60.4 and NC 1CS $\times$ 95LYC (2009) had $56.9 \mathrm{mg} / \mathrm{kg}$ lycopene, respectively. This indicated that lycopene producing genes were dominant over yellow colored genes in tomato. Similar to NC 1CS, hybrids with 28L-1 (2008) produced good levels of lycopene even with yellow colored hybrids (Table 1). This indicated that red color was dominant over other colors, which was reflected in lycopene content.

\subsection{Crosses with Pink Fruited Parent}

Pink fruited parent, NC 161L, was one of the best parents for lycopene content. It produced high level of lycopene when combined with all colored parents including yellow. The best performing hybrid for lycopene was derived from Chocolate Stripe $\times$ NC 161L in this study (Table 1). In the pink fruited tomato, the skin is clear (transparent) and flesh is red. This indicated that pink fruited tomato is dominant for lycopene content in $F_{1}$.

\subsection{Crosses with Blue Fruited Parent}

Blue tomatoes are believed to have higher flavonoid levels rather than lycopene. In fact, lycopene level was towards the low end in this study in blue tomato parent (74CAP (2009)). Hybrids developed with this parent produced relatively low lycopene content except the one with 74CAP (2009) $\times$ Chocolate Stripe $(69.5 \mathrm{mg} / \mathrm{kg})$. This indicated that although less influential in lycopene biosynthesis, blue colored tomato was dominant over yellow (at least $48 \mathrm{mg} / \mathrm{kg}$ lycopene) and green (59.5 mg/kg lycopene) colored tomatoes. However, purple-brown stripe was dominant over blue since the former level was higher over blue tomato in the $F_{1}$ (Table 1).

\subsection{Crosses with Yellow Fruited Parents}

There were four yellow colored parents with different gene combinations in this study namely 72LYC (2009) with the $\beta$-gene, 08133-1(×)-7W with red stripe, 95LYC (2009) with ther-gene, and NC1Y with the tangerine $(t)$ gene. Several interesting hybrid combinations were found for lycopene content. Although both are yellow, hybrid of 72LYC (2009) × 08133-1(×)-7W had almost normal level of lycopene content (51.7 mg/kg). Reduced levels of lycopene were found in the hybrids developed from 72LYC (2009) $\times$ 95LYC (2009) $(39.4 \mathrm{mg} / \mathrm{kg})$, 72LYC $(2009) \times$ NC 1Y $(41.7 \mathrm{mg} / \mathrm{kg}), 08133-1(\times)-7 \mathrm{~W} \times \mathrm{NC} 1 \mathrm{Y}(50.6 \mathrm{mg} / \mathrm{kg})$ and 95LYC $(2009) \times \mathrm{NC} 1 \mathrm{Y}$ $(52.2 \mathrm{mg} / \mathrm{kg})$. However, 08133-1( $\times)-7 \mathrm{~W} \times$ 95LYC (2009) produced extremely low levels of lycopene $(6.8 \mathrm{mg} / \mathrm{kg})$. Furthermore, both of these parents when crossed with Malachite Box either produced extremely low lycopene or 
Table 1. Lycopene content (mg/kg) and color parameters $\left(\mathrm{L}^{*}, \mathrm{a}^{*} \mathrm{~b}^{*}\right.$, hue and chroma) in the parents and $\mathrm{F}_{1}$ hybrids of tomato derived from parents of different color. Observations are the average of four experiments as described in the materials and methods.

\begin{tabular}{|c|c|c|c|c|c|c|}
\hline Parent and hybrids & Lycopene & $\mathrm{L}^{*}$-value & $a^{*}$-value & $b^{*}$-value & Hue & Chroma \\
\hline NC1CS & 69.3 & 46.7 & 34.6 & 31.1 & 41.7 & 46.9 \\
\hline 74CAP(2009) & 52.0 & 47.7 & 18.4 & 29.9 & 58.4 & 35.3 \\
\hline 72LYC(2009) & 43.0 & 61.8 & 19.3 & 42.9 & 66.2 & 47.1 \\
\hline 08133-1(×)-7W & 13.7 & 62.9 & 9.9 & 46.0 & 79.1 & 47.9 \\
\hline 28L-1(2008) & 64.1 & 49.4 & 29.1 & 33.2 & 48.9 & 44.5 \\
\hline 95LYC(2009) & NA & 69.1 & 0.2 & 41.1 & 94.1 & 41.1 \\
\hline NC1Y & 7.7 & 66.1 & 10.0 & 57.4 & 80.8 & 58.3 \\
\hline Chocolate Stripe & 74.9 & 44.2 & 22.0 & 30.3 & 53.9 & 37.7 \\
\hline Malachite Box & 57.3 & 61.7 & -0.1 & 39.2 & 104.5 & 40.1 \\
\hline NC 161L & 64.6 & 47.1 & 31.7 & 32.7 & 45.8 & 45.8 \\
\hline NC1CS $\times 08133-1(\times)-7 W$ & 61.4 & 48.0 & 30.2 & 32.2 & 47.1 & 44.5 \\
\hline NC1CS × 28L-1(2008) & 61.4 & 46.6 & 32.3 & 31.5 & 44.1 & 45.4 \\
\hline NC1CS × 72LYC(2009) & 43.5 & 54.3 & 25.1 & 36.2 & 55.4 & 44.2 \\
\hline NC1CS × 74CAP(2009) & 62.2 & 49.7 & 26.7 & 32.8 & 50.6 & 42.6 \\
\hline NC1CS × 95LYC(2009) & 56.9 & 49.2 & 28.6 & 33.5 & 49.6 & 44.2 \\
\hline NC1CS $\times$ Chocolate Stripe & 66.1 & 47.2 & 33.4 & 32.3 & 43.9 & 46.8 \\
\hline NC1CS $\times$ Malachite Box & 64.6 & 47.7 & 31.0 & 32.6 & 46.4 & 45.4 \\
\hline NC1CS $\times$ NC 161L & 63.5 & 48.2 & 32.5 & 31.4 & 43.9 & 45.8 \\
\hline $\mathrm{NC1CS} \times \mathrm{NC1Y}$ & 60.4 & 50.3 & 30.2 & 33.7 & 48.0 & 45.9 \\
\hline 74CAP(2009) × 08133-1(×)-7W & 50.6 & 48.5 & 23.9 & 33.4 & 54.2 & 41.3 \\
\hline 74CAP(2009) × 28L-1(2008) & 50.2 & 46.1 & 24.5 & 32.1 & 52.6 & 40.6 \\
\hline 74CAP(2009) × 72LYC(2009) & 48.0 & 51.9 & 22.0 & 37.8 & 59.9 & 43.8 \\
\hline 74CAP(2009) × 95LYC(2009) & 52.8 & 48.7 & 21.2 & 33.8 & 58.0 & 40.1 \\
\hline 74CAP(2009) $\times$ Chocolate Stripe & 69.5 & 46.6 & 26.7 & 32.1 & 50.0 & 42.1 \\
\hline 74CAP(2009) × Malachite Box & 59.5 & 45.8 & 24.1 & 32.1 & 52.9 & 40.3 \\
\hline 74CAP(2009) × NC 161L & 55.7 & 46.6 & 26.2 & 31.4 & 49.8 & 41.1 \\
\hline 74CAP(2009) $\times$ NC1Y & 52.1 & 48.7 & 24.9 & 33.6 & 53.4 & 42.0 \\
\hline 72LYC(2009) × 08133-1(×)-7W & 51.7 & 52.6 & 25.2 & 36.9 & 56.4 & 45.2 \\
\hline 72LYC(2009) × 28L-1(2008) & 47.3 & 50.2 & 27.3 & 34.9 & 51.9 & 44.7 \\
\hline 72LYC(2009) × 95LYC(2009) & 39.4 & 54.2 & 21.5 & 39.3 & 61.1 & 45.3 \\
\hline 72LYC(2009) $\times$ Chocolate Stripe & 62.3 & 48.2 & 30.3 & 33.1 & 47.4 & 45.2 \\
\hline 72LYC(2009) × Malachite Box & 43.0 & 50.8 & 25.1 & 37.5 & 56.1 & 45.9 \\
\hline 72LYC(2009) × NC 161L & 40.9 & 53.7 & 24.7 & 37.0 & 57.2 & 45.0 \\
\hline 72LYC(2009) $\times$ NC1Y & 41.7 & 56.5 & 23.7 & 40.1 & 59.7 & 46.6 \\
\hline
\end{tabular}




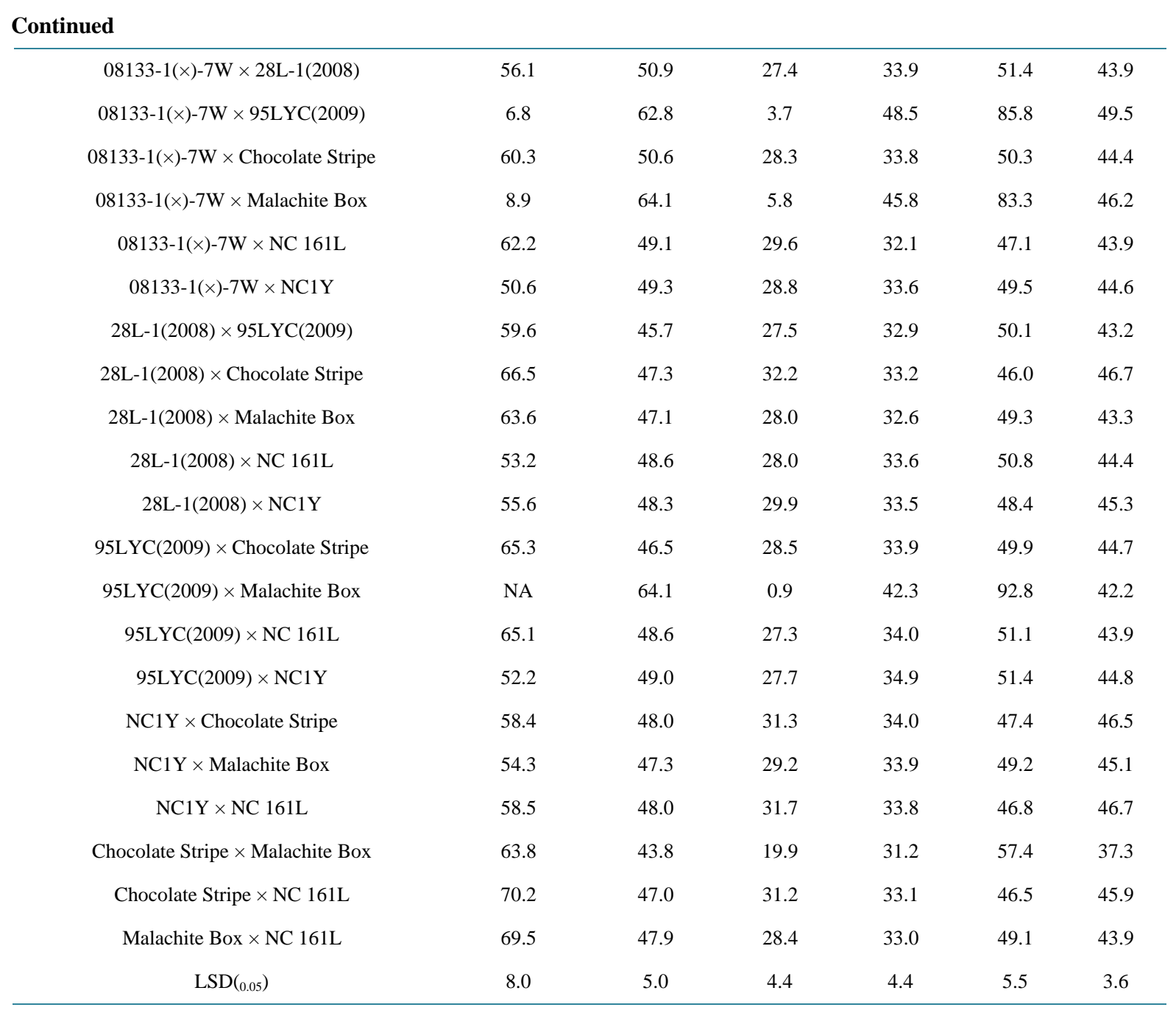

did not produce at all (Table 1). This indicated that yellow color was dominant over green suppressing lycopene content production.

\subsection{Crosses with Green Fruited Parent}

Malachite Box was the only green flesh parent in this study. When crossed with other colored parents, lycopene content was found to be influenced by the gene of other parent (Table 1). This indicated that green flesh color was recessive to almost all of the colors in this study.

\subsection{Analysis of Variance}

There was a significant difference $(p<0.05)$ among genotypes for lycopene content and color parameters including $\mathrm{L}^{*}$-value, $\mathrm{a}^{*}$-value, $\mathrm{b}^{*}$-value, hue and chroma (Table 2). However, there was no interaction $(p>0.05)$ between genotypes and environments for lycopene content indicating that the level of lycopene was consistent across the experiments, and lycopene content is not influenced by environment.

\subsection{Combining Ability Analysis}

Parents were found to be significantly different for general combining ability (GCA). Based on the GCA, the best parent with positive contribution to lycopene content was Chocolate Stripe followed by NC 1CS, 28L-1 (2008) and NC 161L, respectively. Other parents including Malachite Box, NC 1Y, 72LYC (2009), 08133- 
Table 2. Analysis of variance for the lycopene and color parameters $\left(\mathrm{L}^{*}, \mathrm{a}^{*}, \mathrm{~b}^{*}\right.$, hue and chroma) over environments.

\begin{tabular}{|c|c|c|c|c|c|c|c|c|c|c|c|c|c|}
\hline \multirow{2}{*}{ Source } & \multirow{2}{*}{ DF } & \multicolumn{4}{|c|}{ Mean square } & \multicolumn{8}{|c|}{ F-value } \\
\hline & & Lycopene & e L ${ }^{*}$-value & a*-value & $b^{*}$-value & Hue & Chroma & Lycopene & $\mathrm{L}^{*}$-value & a*-value & $b^{*}$-value & Hue & Chroma \\
\hline ENV & 3 & 3429.5 & 3367.2 & 2599.8 & 3169.0 & 5317.5 & 2716.9 & $6.56^{* *}$ & $533.77^{* * *}$ & $420.83^{* * *}$ & $1155.28^{* * *}$ & $438.26^{* * *}$ & $1266.18^{* * *}$ \\
\hline REP (ENV) & 8 & 920.2 & 35.7 & 15.7 & 5.6 & 26.6 & 7.5 & $1.76 \mathrm{~ns}$ & $5.67^{* * * *}$ & $2.53^{*}$ & $2.03^{*}$ & $2.19^{*}$ & $3.49^{* *}$ \\
\hline ENTRY & 54 & 962.6 & 416.1 & 839.5 & 284.6 & 2164.0 & 126.4 & $1.84^{* *}$ & $65.96^{* * * *}$ & $135.89^{* * * *}$ & $103.75^{* * *}$ & $178.35^{* * *}$ & $58.92^{* * *}$ \\
\hline ENV ${ }^{*}$ ENTRY & 162 & 508.7 & 14.5 & 21.2 & 9.0 & 38.3 & 8.2 & $0.97 \mathrm{~ns}$ & $2.31^{* * * *}$ & $3.43^{* * *}$ & $3.27^{* * *}$ & $3.16^{* * * *}$ & $3.8^{* * * *}$ \\
\hline
\end{tabular}

1( $\times$ )-7W and 74CAP (2009) were the negative contributors to the lycopene content in the hybrids, respectively (Table 3). There was no difference among the parents for specific combining ability (SCA). Although statistically it was non-significant, a few combinations were notable. All hybrids with Chocolate Stripe and NC 1CS had positive gain for lycopene content whereas those with 28L-1(2008) and 74CAP (2009) had a mixture of positive and negative contribution with different parents. Other parents either did not have any contribution at all or there was a negative contribution for lycopene content. There was no GCA x environment and SCA x environment interaction for lycopene content (Table 3).

\subsection{Heritability Estimates}

In order to estimate the heritability from the variance components, parameters were estimated as described by Zhang, Kang [29]. Narrow-sense heritability for lycopene was only 9\% whereas broad-sense heritability estimate was $25 \%$. Narrow-sense and broad-sense heritability estimates for $L^{*}$-value, $a^{*}$-value, $b^{*}$-value, hue and chroma were close to that of lycopene (Table 4).

\subsection{Correlation between Lycopene and Color Parameters}

When lycopene data were examined against color parameters, there was a negative correlation with $\mathrm{L}^{*}$-value $(r$ $=-0.77)$ and $\mathrm{b}^{*}$-value $(r=-0.79)$ whereas it was positive with $\mathrm{a}^{*}$-value $(r=0.67)$ and hue $(r=0.89)$. There was no correlation at all between lycopene and chroma $(r=0.06)$. This pattern is presented in Figure 1. Generally $L^{*}$-value represents the lightness of the color which means lack of redness. Similarly, $b^{*}$-value means yellow light which means no lycopene, which are negatively correlated. On the other hand, $\mathrm{a}^{*}$-value indicates the intensity of redness, which means there is more lycopene which is what we have found in the present study.

\section{Discussion}

Bicolor parent Chocolate Stripe (purple-brown) was found to have the highest lycopene content level among the ten parents. Most of the parents were not analyzed for lycopene content before other than NC 1CS [21], which was one of the superior parents in this study. This might be because of presence of the "crimson" gene. The crimson gene has been reported to increase the level of lycopene in tomato by up to $74 \%$ [30]. However, in our previous study, it was not proved to be true [31]. In the present study, a clear association between fruit color and lycopene level was established, which was not new information. However, inheritance of fruit color and lycopene level, and color parameters ( $\mathrm{L}, \mathrm{a}^{*}, \mathrm{~b}^{*}$, hue and chroma) in $\mathrm{F}_{1 \mathrm{~s}}$ found in the present study was novel.

In the present study, the order of dominance was bi-color (purple-brown) $>$ red $>$ blue $>$ yellow $>$ green. Level of lycopene was in this order when hybrids were produced by crossing different colored parents. There are limited numbers of published studies supporting this finding since studies were not conducted towards this direction before.

Heritability estimates found in the present study were less than in some of the past studies [32] [33]. This may be from the conservative estimates used in the present study. However, these estimates were similar to what have been reported in our one of the recent studies [34]. In previous studies there was a significant GxE interaction and a non-significant GxEinteraction was found in the present study. That means, a higher level of genetic control for lycopene content was expected in the present study. However, the heritability estimate was towards the low end. Narrow-sense heritability estimates for lycopene estimated by theparent-hybrid regression method were found to be $65 \%$ in yet another study [16]. 


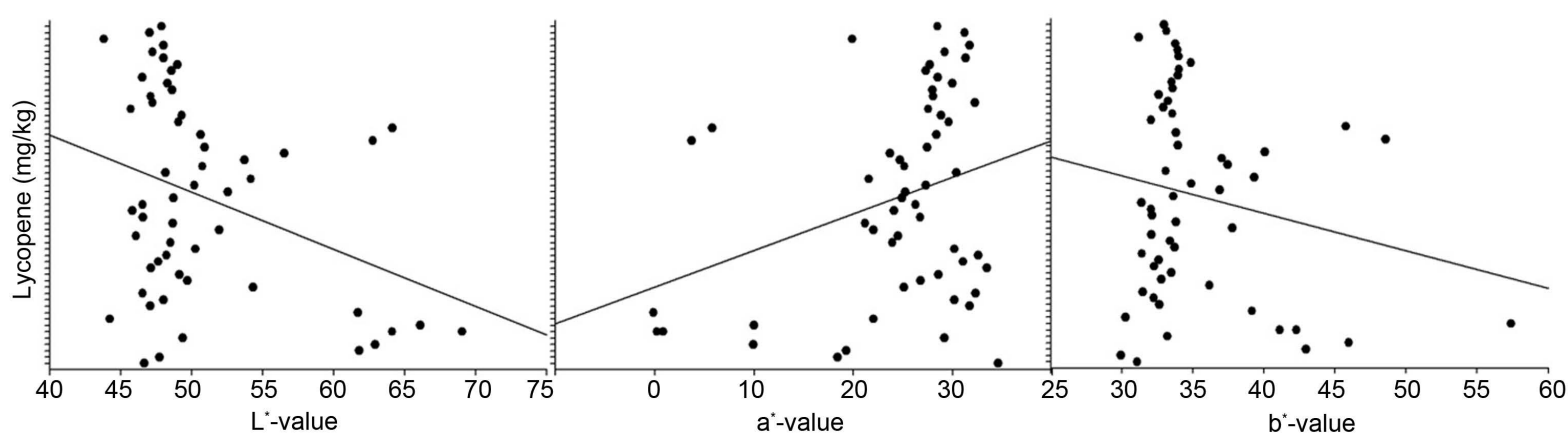

Figure 1. Relationship between lycopene and color parameters. Overall, correlation between lycopene and $\mathrm{L}^{*}$-value was -0.77 , lycopene and $a^{*}$-value was 0.67 , and lycopene and $b^{*}$-value was -0.79 in this study. Correlation between lycopene and hue was 0.89 whereas that between lycopene and chroma was 0.06 .

Table 3. Analysis of variance for the lycopene and color parameters $\left(\mathrm{L}^{*}, \mathrm{a}^{*}, \mathrm{~b}^{*}\right.$, hue and chroma) over environments for general combining ability (GCA) and specific combining ability (SCA).

\begin{tabular}{|c|c|c|c|c|c|c|c|c|c|c|c|c|c|}
\hline \multirow{2}{*}{ Source } & \multirow{2}{*}{$\mathrm{DF}$} & \multicolumn{4}{|c|}{ Mean square } & \multicolumn{8}{|c|}{ F-value } \\
\hline & & Lycopene & $\mathrm{L}^{*}$-value & $a^{*}$-value & $b^{*}$-value & Hue & Chroma & Lycopene & $L^{*}$-value & $a^{*}$-value & $b^{*}$-value & Hue & Chroma \\
\hline GCA & 9 & 2260.4 & 532.1 & 1418.5 & 410.4 & 3021.7 & $7 \quad 147.4$ & $4.3^{* *}$ & $84.4^{* * * *}$ & $229.6^{* * * *}$ & $149.6^{* * *}$ & $249.1^{* * *}$ & $68.7^{* * * *}$ \\
\hline SCA & 45 & 1100.6 & 169.8 & 308.4 & 99.4 & 747.0 & 35.0 & $2.1^{* *}$ & $26.9^{* * * *}$ & $49.9^{* * *}$ & $36.2^{* * *}$ & $61.6^{* * *}$ & $16.3^{* * *}$ \\
\hline GCA ENV & 27 & -750.3 & 72.2 & 110.1 & 9.0 & 340.8 & 14.8 & -1.4 & $11.4^{* * * *}$ & $17.8^{* * *}$ & $3.3^{* * *}$ & $28.1^{* * *}$ & $6.9^{* * * *}$ \\
\hline SCA $^{*}$ ENV & 135 & -366.0 & 31.8 & 61.5 & 10.7 & 158.7 & 2.5 & -0.7 & $5.0^{* * *}$ & $9.9^{* * * *}$ & $3.9^{* * *}$ & $13.1^{* * *}$ & 1.1 \\
\hline
\end{tabular}

Table 4. Variance component estimates for lycopene and color parameters $\left(\mathrm{L}^{*}, \mathrm{a}^{*}, \mathrm{~b}^{*}\right.$, hue and chroma) in tomato. The components were calculated by the method as described by Zhang, Kang [29].

\begin{tabular}{|c|c|c|c|c|c|c|}
\hline Parameter & Lycopene & $\mathrm{L}^{*}$-value & $a^{*}$-value & $\mathrm{b}^{*}$-value & Hue & Chroma \\
\hline Additive variance $\left(\mathrm{V}_{\mathrm{A}}\right)$ & -14.07 & 1.35 & 2.06 & 0.17 & 6.39 & 0.28 \\
\hline Dominance variance $\left(\mathrm{V}_{\mathrm{D}}\right)$ & -23.7 & 2.1 & 4.0 & 0.7 & 10.3 & 0.2 \\
\hline Error variance $\left(\mathrm{V}_{\mathrm{E}}\right)$ & -114.7 & 10.1 & 18.9 & 3.1 & 50.1 & 1.0 \\
\hline Narrow-sense heritability $\left(h^{2}\right)$ & 0.09 & 0.10 & 0.08 & 0.04 & 0.10 & 0.20 \\
\hline Broad-sense heritability (H) & 0.25 & 0.25 & 0.24 & 0.22 & 0.25 & 0.31 \\
\hline Dominance ratio & 1.69 & 1.52 & 1.93 & 4.12 & 1.61 & 0.58 \\
\hline
\end{tabular}

\section{Conclusion}

Overall, we have reported the inheritance of different color parameters and lycopene content in an $\mathrm{F}_{1}$ derived from different colored parents of tomato. With the information of inheritance and dominance for lycopene, it may be useful to design and develop populations aiming to improve lycopene content in tomato or specialty tomato with different colors for special markets.

\section{Acknowledgements}

This research was supported in part by grants from the North Carolina Department of Agriculture, Specialty Crop Block Grant Program and the North Carolina Tomato Growers Association. The technical help of Dr. Guoying Ma, Tyler Nance and Adrienne Ratti is highly appreciated.

\section{References}

[1] Male, C.J. (1999) 100 Heirloom Tomatoes for the American Garden. Workman Publishing, New York. 
[2] Lu, S. and Li, L. (2008) Carotenoid Metabolism: Biosynthesis, Regulation, and Beyond. Journal of Integrative Plant Biology, 50, 778-785. http://dx.doi.org/10.1111/j.1744-7909.2008.00708.x

[3] Fray, R.G. and Grierson, D. (1993) Identification and Genetic-Analysis of Normal and Mutant Phytoene Synthase Genes of Tomato by Sequencing, Complementation and Co-Suppression. Plant Molecular Biology, 22, 589-602. http://dx.doi.org/10.1007/BF00047400

[4] Gady, A.L.F., et al. (2012) Induced Point Mutations in the Phytoene Synthase 1 Gene Cause Differences in Carotenoid Content during Tomato Fruit Ripening. Molecular Breeding, 29, 801-812. http://dx.doi.org/10.1007/s11032-011-9591-9

[5] Liu, L.H., et al. (2015) Regulation of Carotenoid Metabolism in Tomato. Molecular Plant, 8, 28-39. http://dx.doi.org/10.1016/j.molp.2014.11.006

[6] Apel, W. and Bock, R. (2009) Enhancement of Carotenoid Biosynthesis in Transplastomic Tomatoes by Induced Lycopene-to-Provitamin A Conversion. Plant Physiology, 151, 59-66. http://dx.doi.org/10.1104/pp.109.140533

[7] Ballester, A.R., et al. (2010) Biochemical and Molecular Analysis of Pink Tomatoes: Deregulated Expression of the Gene Encoding Transcription Factor S1MYB12 Leads to Pink Tomato Fruit Color. Plant Physiology, 152, 71-84. http://dx.doi.org/10.1104/pp.109.147322

[8] Caputo, M., et al. (2004) Antioxidant Profiles of Corbara Small Tomatoes during Ripening and Effects of Aqueous Extracts on J774 Cell Antioxidant Enzymes. Journal of Food Biochemistry, 28, 1-20. http://dx.doi.org/10.1111/j.1745-4514.2004.tb00052.x

[9] Aydemir, G., et al. (2013) Lycopene-Derived Bioactive Retinoic Acid Receptors/Retinoid-X Receptors-Activating Metabolites May Be Relevant for Lycopene’s Anti-Cancer Potential. Molecular Nutrition \& Food Research, 57, 739747. http://dx.doi.org/10.1002/mnfr.201200548

[10] Lee, S.T., et al. (2013) Alpha-Tomatine Synergises with Paclitaxel to Enhance Apoptosis of Androgen-Independent Human Prostate Cancer PC-3 Cells in Vitro and in Vivo. Phytomedicine, 20, 1297-1305. http://dx.doi.org/10.1016/j.phymed.2013.07.002

[11] Labate, J.A., Robertson, L.D., Wu, F., Tanksley, S.D. and Baldo, A.M. (2009) EST, COSII, and Arbitrary Gene Markers Give Similar Estimates of Nucleotide Diversity in Cultivated Tomato (Solanum lycopersicum L.). Theoretical and Applied Genetics, 118, 1005-1014. http://dx.doi.org/10.1007/s00122-008-0957-2

[12] Yang, K., Lule, U.S. and Ding, X.-L. (2006) Lycopene: Its Properties and Relationship to Human Health. Food Reviews International, 22, 309-333. http://dx.doi.org/10.1080/87559120600864753

[13] Oltman, A.E., Jervis, S.M. and Drake, M.A. (2014) Consumer Attitudes and Preferences for Fresh Market Tomatoes. Journal of Food Science, 79, S2091-S2097. http://dx.doi.org/10.1111/1750-3841.12638

[14] Unlu, N.Z., Bohn, T., Francis, D., Clinton, S.K. and Schwartz, S.J. (2007) Carotenoid Absorption in Humans Consuming Tomato Sauces Obtained from Tangerine or High-Beta-Carotene Varieties of Tomatoes. Journal of Agricultural and Food Chemistry, 55, 1597-1603. http://dx.doi.org/10.1021/jf062337b

[15] Schnabele, K., Briviba, K., Bub, A., Roser, S., Pool-Zobel, B.L. and Rechkemmer, G. (2008) Effects of Carrot and Tomato Juice Consumption on Faecal Markers Relevant to Colon Carcinogenesis in Humans. British Journal of Nutrition, 99, 606-613. http://dx.doi.org/10.1017/S0007114507819143

[16] Causse, M., Buret, M., Robini, K. and Verschave, P. (2003) Inheritance of Nutritional and Sensory Quality Traits in Fresh Market Tomato and Relation to Consumer Preferences. Journal of Food Science, 68, 2342-2350. http://dx.doi.org/10.1111/j.1365-2621.2003.tb05770.x

[17] Gardner, R.G. (2006) "Plum Crimson” Fresh-Market Plum Tomato Hybrid and Its Parents, NC EBR-7 and NC EBR-8. Hortscience, 41, 259-260.

[18] Gardner, R.G. (2006) “Mountain Crest” Hybrid Tomato and Its Parent, NC 1 rinEC. Hortscience, 41, 261-262.

[19] Liu, Y.-S., Gur, A., Ronen, G., Causse, M., Damidaux, R., Buret, M., et al. (2003) There Is More to Tomato Fruit Colour than Candidate Carotenoid Genes. Plant Biotechnology Journal, 1, 195-207. http://dx.doi.org/10.1046/j.1467-7652.2003.00018.x

[20] Vogel, J.T., Tieman, D.M., Sims, C.A., Odabasi, A.Z., Clark, D.G. and Klee, H.J. (2010) Carotenoid Content Impacts Flavor Acceptability in Tomato (Solanum lycopersicum). Journal of the Science of Food and Agriculture, 90, 22332240. http://dx.doi.org/10.1002/jsfa.4076

[21] Panthee, D.R. and Gardner, R.G. (2011) “Mountain Majesty”: A Tomato Spotted Wilt Virus-Resistant Fresh-Market Hybrid Tomato and Its Parents NC 714 and NC 1CS. Hortscience, 46, 1321-1323.

[22] Panthee, D.R. and Gardner, R.G. (2014) "Mountain Rouge”: A Pink-Fruited, Heirloom-Type Hybrid Tomato and Its Parent Line NC 161L. Hortscience, 49, 1463-1464.

[23] Darrigues, A., Hall, J., van der Knaap, E. and Francis, D.M. (2008) Tomato Analyzer-Color Test: A New Tool for Ef- 
ficient Digital Phenotyping. Journal of the American Society for Horticultural Science, 133, 579-586.

[24] Rodríguez, G.R., Moyseenko, J.B., Robbins, M.D., Morejón, N.H., Francis, D.M. and van der Knaap, E. (2010) Tomato Analyzer: A Useful Software Application to Collect Accurate and Detailed Morphological and Colorimetric Data from Two-Dimensional Objects. Journal of Visualized Experiments, 37, 1-9. http://dx.doi.org/10.3791/1856

[25] Davis, A.R., Fish, W.W. and Perkins-Veazie, P. (2003) A Rapid Spectrophotometric Method for Analyzing Lycopene Content in Tomato and Tomato Products. Postharvest Biology and Technology, 28, 425-430. http://dx.doi.org/10.1016/S0925-5214(02)00203-X

[26] Perkins-Veazie, P., Collins, J.K. and Roberts, W. (2006) Lycopene Content of Organically Grown Tomatoes. Hortscience, 41, 503-503.

[27] SAS Institute Inc. (2011) The SAS System, Version 9.3 for Windows. 9th Edition, SAS Institute, Cary.

[28] Griffing, B. (1956) Concept of General and Specific Combining Ability in Relation to Diallel Crossing Systems. Australian Journal of Biological Sciences, 9, 463-493.

[29] Zhang, Y.D., Kang, M.S. and Lamkey, K.R. (2005) DIALLEL-SAS05: A Comprehensive Program for Griffing’s and Gardner-Eberhart Analyses. Agronomy Journal, 97, 1097-1106. http://dx.doi.org/10.2134/agronj2004.0260

[30] Thompson, K.A., Marshall, M.R., Sims, C.A., Wei, C.I., Sargent, S.A. and Scott, J.W. (2000) Cultivar, Maturity, and Heat Treatment on Lycopene Content in Tomatoes. Journal of Food Science, 65, 791-795. http://dx.doi.org/10.1111/j.1365-2621.2000.tb13588.x

[31] Panthee, D.R., Perkins-Veazie, P., Randall, D. and Allan, F. (2013) Lycopene Estimation in Tomato Lines Using Infra-Red Absorbance and Tomato Analyzer. International Journal of Vegetable Science, 19, 240-255. http://dx.doi.org/10.1080/19315260.2012.715324

[32] Prema, G., Indiresh, K.M. and Santhosha, H.M. (2011) Studies on Genetic Variability in Cherry Tomato (Solanum lycopersicum var. Cerasiforme). Asian Journal of Horticulture, 6, 207-209.

[33] Panthee, D.R., Cao, C.X., Debenport, S.J., Rodríguez, G.R., Labate, J.A., Robertson, L.D., et al. (2012) Magnitude of Genotype x Environment Interactions Affecting Tomato Fruit Quality. Hortscience, 47, 721-726.

[34] Panthee, D.R., Labate, J.A., McGrath, M.T., Breksa III, A.P. and Robertson, L.D. (2013) Genotype and Environmental Interaction for Fruit Quality Traits in Vintage Tomato Varieties. Euphytica, 193, 169-182. http://dx.doi.org/10.1007/s10681-013-0895-1 